\title{
INFECTIVITY OF AMASTIGOTES OF TRYPANOSOMA CRUZI
}

\author{
Tecia Ulisses de CaRVaLfo \& Wanderley de Souza (*)
}

\section{S U M M A R Y}

The infectivity amastigotes of Trypanosoma cruzi, isolated from the supernatant of the J774G8 macrophage-like cell line infected with trypomastigotes to normal macrophages in vitro was tested. After a period of $I \mathrm{~h}$ of $\mathbf{T}$. cruzi-macrophage interaction about $2 \%$ of the mouse peritoneal macrophages had ingested amastigotes. In contrast $12 \%$ of the macrophages had ingested epimastigotes. Treatment of the amastigotes with trypsin did not interfere with their ingestion by macrophages. Once inside the macrophages the amastigotes divided and after some days transformed into trypomastigotes. When i.p. inoculated into mice the amastigotes were highly infective, inducing high levels of parasitaemia and tissue parasitism. As previously described for trypomastigotes, amastigotes were not lysed when incubated in the presence of fresh guinea-pig serum. Contrasting with what has been described for trypomastigotes, the resistance of amastigotes to complement-mediated lysis persisted after treatment with trypsin.

KEY WORDS: - Chagas'disease - Trypanosoma cruzi - Experimental infection in mice - Infectivity of amastigotes

\section{N T ROD U C T IO N}

Three developmental stages exist in the life cycle of Trypanosoma cruzi: epimastigote, trypomastigote and amastigote. The first stage is the dividing form, found in the intestine of the invertebrate host and can be easily maintained in vitro in axenic culture. The trypomastigote stage is not able to divide. It can be found in the intestine of the invertebrate host and in the bloodstream of the vertebrate host. This form is able to infect most of the vertebrate cells, where it transforms into the amastigote stage. This amastigote is the only form of $\mathbf{T}$. cruzi in the vertebrate under which multiplication occurs and is, therefore, responsible for the pa. rasitological amplification of Chagas'disease.

It has been shown conclusively that epimastigote and trypomastigote forms of $\mathbf{T}$. cruzi are ingested by macrophages. However, while epimastigotes are digested, trypomastigotes survive and divide within normal macrophages (NOGUEIRA \& COHN ${ }^{19}$ ). Therefore, while epi. mastigotes are not infective, trypomastigotes are highely infective to the vertebrate host Few data exist on the infectivity of amastigo. tes to the vertebrate host due to the difficulties in obtaining parasites which can be safely iden. tified as amastigotes and which are not altered by the drastic treatments with which they were obtained. Using amastigote-like forms from different sources, contradictory results have been reported (ABRAHAMSON et al. 1; ARAUJO et al ${ }^{3}$; CARVALHO et al. 6; GUTTERIDGE et al. 10; HUDSON et al.11; LANAR 13; MACCABE et al 14; PAN 23; RIBEIRO et al ${ }^{24}$; SEGURA et al. 25 ;

Laboratório de vitra-estrutura Celular. Instituto de Biofísica. Universidade Federal do Rio de Janeiro. Centro de Ciências da Saúde - Bloco G. Cidade Universitária CEP 2194I - Rio de Janeiro, RJ - BrasiJ (*) For all correspondence. 
CARVALHO, T. U. de \& SOUZA, W. de - Infectivity of amastigotes of Trypanosoma cruzi. Rev. Inst. Med. trop. São Paulo, 28:205-212, 1986.

UMEZAWA et al. 26; VILLALTA \& KIERSZEN. BAUM 27 . For some Authors amastigotes are infective while for others. they are immediately digested by macrophages.

We described recently a procedure for obtaining amastigotes of T. cruzi (CARVALHO \& SOUZA ${ }^{7}$ ) and showed, by freeze-fracture and determination of the surface charge (CARVALHO et al. ${ }^{8}$, that the forms obtained by us have surface properties which distinguish them from epimastigotes and trypomastigotes. In the present work we report the effect of complement on amastigotes of $\mathbf{T}$. cruzi and their infectivity to mice and to mouse peritoneal macrophages maintained in vitro.

\section{MATERIALS AND METHODS}

\section{Cell Interaction}

The $\mathrm{Y}$ strain of $\mathbf{T}$. cruxi was used. It had been maintained by weekly i.p. injections in mice. Trypomastigotes were obtained from the blood of mice 7 days post inoculation. Epimastigotes were cultivated for 4 days in Warren's medium (WARREN ${ }^{28}$ ). For isolation of amastigotes we used, as previously described, the macrophage-like cell line J774G8 (CARVALHO \& SOUZA ${ }^{7}$ ). The cells were infected with bloodstream trypomastigotes and the cultures examined every day using an inverted microscope. When a large number of amastigotes were seen in the supernatant they were isolated by cen. trifugation in a Metrizamide gradient. The cells were processed for electron microscopy as described previously (CARVALHO \& SOUZA ${ }^{7}$ ).

Macrophages were collected from the peri. toneal cavities of uninfected Swiss mice after injection of 3 to $5 \mathrm{mls}$ of Hank's balanced solution (HBS). Samples of a $0.6 \mathrm{ml}$ suspension containing $2 \times 10^{6}$ mononuclear cells per $\mathrm{ml}$ were placed into Leighton tubes with flying cover.slips. After incubation for about $1 \mathrm{hr}$ at $37^{\circ} \mathrm{C}$ the non-adherent cells were removed, the macrophage monolayers were washed bwice with 199 medium and new 199 medium supplemented with $10 \%$ inactivated fetal calf serum was added and the cells were incubated for $\mathbf{2 4}$ hrs at $37^{\circ} \mathrm{C}$. Parasites (amastigotes, epimastigotes) were suspended in 199 medium in order to achieve a ratio of 10 parasites per macrophage, and $0.5 \mathrm{ml}$ of the súspensions was added to the macrophage cultures. Parasites were maintained in contact with the macrophages for periods varying from 1 to $24 \mathrm{~h}$ after which ti. me the cells were rinsed with Ringer solution, fixed with Bouin's fixative and then stained with Giemsa. The percentage of infected ma crophages was determined by randomly examining at least 200 cells in triplicates with high magnification under a Zeiss Universal Photomicroscope. The experiments were repeated at least 3 times. In some experiments, after 120 min. of interaction the cultures were washed twice with HBS to remove extracellular parasites, new 199 medium supplemented with $10 \%$ fetal calf serum was added and then incubated at $37^{\circ} \mathrm{C}$ for periods varying from 1 to 6 days At intervals of $24 \mathrm{hs}$ the culture medium was changed. These cultures were also fixed with Bouin's fixative and stained with Giemsa.

\section{Enzymatic Treatment}

Amastigotes and trypomastigotes were washed twice with 199 medium and then incubated for $15 \mathrm{~min}$. at $37^{\mathrm{a}} \mathrm{C}$ in the presence of $500 \mu \mathrm{g} / \mathrm{ml}$ of trypsin (Sigma Chemical Compa. ny, type III) dissolved in 199 medium without serum, $\mathrm{pH} 7.2$, or for $30 \mathrm{~min}$. at $37^{\mathrm{a}} \mathrm{C}$ in the presence of $0.2 \mathrm{U} / \mathrm{ml}$ of neuraminidase (Sigma, type $\mathrm{X}$ from Clostridium perfringens) in Tyrode's solution, $\mathrm{pH}$ 6.0. The effect of trypsin was stopped by addition of fetal calf serum. After enzyme treatment the cells were collected by centrifugation, 'washed twice in Tyrode's solution or 199 medium without serum and used for experiments of interaction with macrophages and complement-mediated lysis.

\section{Lytic Assays}

To measure lysis by complement, $100 \mu \mathrm{l}$ of control or enzyme treated parasites were mixed with $100 \mu \mathrm{l}$ of normal pig serum and incubated for $30 \mathrm{~min}$. at $37^{\circ} \mathrm{C}$. Aliquots were examined in a Neubauer Chamber before and after the in cubation of the parasites in the presence of se. rum. The number of viable parasites, determined by using the trypan blue exclusion test, was expressed as the mean of two replicated tubes.

\section{Infectivity to Mice}

Groups of 12 mice were inoculated intrape ritoneally wich $10^{5}$ isolated amastigotes or blood- 
CARvalho, T U. de \& SOUZA, W. de - Infectivity of amastigotes of Trypanosoma cruzi. Rev. Inst. Med. trop. São Paulo, 28:205-212, 1986.

stream trypomastigotes. Parasitaemia was recorded every $48 \mathrm{hs}$. Six mice were, 10 days after inoculation, sacrificed and fragments from liver, heart and spleen were removed, fixed in 10\% formaldehyde, and embebbed in paraffin. Five to $10 \mu \mathrm{m}$ sections were obtained, stained with hematoxylin-eosin and observed under the $\mathrm{mi}$ croscope.

\section{RESULTS}

By using the methodology previously described for obtaining of amastigotes, very pure preparations were obtained some of which con. taining less than $0.1 \%$ of typical trypomastigotes (Fig. 1). In some experiments, for unknown reasons, the preparaticns obtained contained about $2 \%$ trypomâstigotes. However, for the experiments described here only pure preparations of amastigotes were used. Examinations of thin sections of these preparations by trans. mission electron microscopy showed that they contained some forms apparently in transition to trypomastigotes (Figs. 4-5). These forms had a kinetoplast with a structure typical of amas. tigotes but located laterally in relation to the nucleus. They also possessed a flagellum sligh. thy larger than that of amastigotes. By using the trypan blue exclusion test, we found that more than $95 \%$ of the cells were viable.

When incubated in vitro in the presence of normal mouse peritoneal macrophages amasti. gotes were ingested by the macrophages. However, the percertage of macrophages which ingested the amastigotes was much lower than that observed, under the same experimental conditions, for epimastigotes. Incubation of the amastigotes in the presence of trypsin before interaction did not increase their ingestion by the macrophages (Table I).

Observation by light microscopy of ma crophage cultures fixed at various times after infection with amastigotes showed that the pa. rasites were not digested, and dividing forms could be observed after 24 hs. (Fig. 2). After 72 hs. of infection the macrophages contained a large number of intracellular parasites, even trypomastigotes and intermediate forms (Figs 3). After longer periods of interaction, trypomastigotes were released into the culture medium. Intracellular development of T. cruzi was observed in practically all macrophages which had ingested amastigotes.

Bloodstream trypomastigotes were seen in mice inoculated intraperitoneally with amasti. gotes. The parasitaemia was high (Fig. 7). The pattern of parasitaemic curve obtained with amastigotes was identical with that observed with bloodstream trypomastigotes, showing a peak at the $7^{\text {th }}$ day and a decline thereafter. About $50 \%$ of the mice inoculated with $10^{5}$ amastigotes died between day 13 and 15. Histopathological analysis of mice sacrificed 10 days after inoculation showed a marked parasitism of tissues (Fig. 6) and no apparent differ. ence was observed in the grade of parasitism of mice inoculated with amastigotes or with bloodstream trypomastigotes. A large number of trypomastigotes was also observed in the peritoneal fluid of the mice.

Amastigotes were not lysed when incubat. ed in the presence of normal, non inactivated guinea pig serum (Table II). We used blood. stream trypomastigotes and epimastigotes as controls. As described before, trypomastigotes were not while all epimastigotes were readly Iysed. It had been shown previously that treatment of bloodstream trypomastigotes with trip. sin renders them susceptible to complementmediated lysis (KIPNIS et al, ${ }^{12}$ ). Our experiments confirmed these observations but showed that the same trypsin treatment did not inter. fere with the resistance of amastigotes to the lysis induced by guinea pig serum (Table II).

\section{DISCUSSION}

The infectivity of the amastigote form of Trypanosoma cruzi to the vertebrate host is still discussed. Some authors have reported that amastigotes are infective while for other they are not. It is possible that these discrepancies result (a) from the origin of the amas. tigote or amastigote-like forms used, and/or (b) from the methods used to obtain them.

Rounded forms, which have been considered amastigotes, have been obtained in axenic cultures under certain conditions (ENGEL et al. 9; PAN 21,22,23). When the Brazil strain is maintained in a special medium at $37^{\circ} \mathrm{C}$, amastigotes are obtained which are able to infect human skin-muscle cells in vitro and mouse pe- 
CARVALHO, T. U. de \& SOUZA, W. de - Infectivity of amastigotes of Trypanosoma cruzi. Rev. Inst. Med, trop. Biso Paulo, 28:205-212, 1986 .

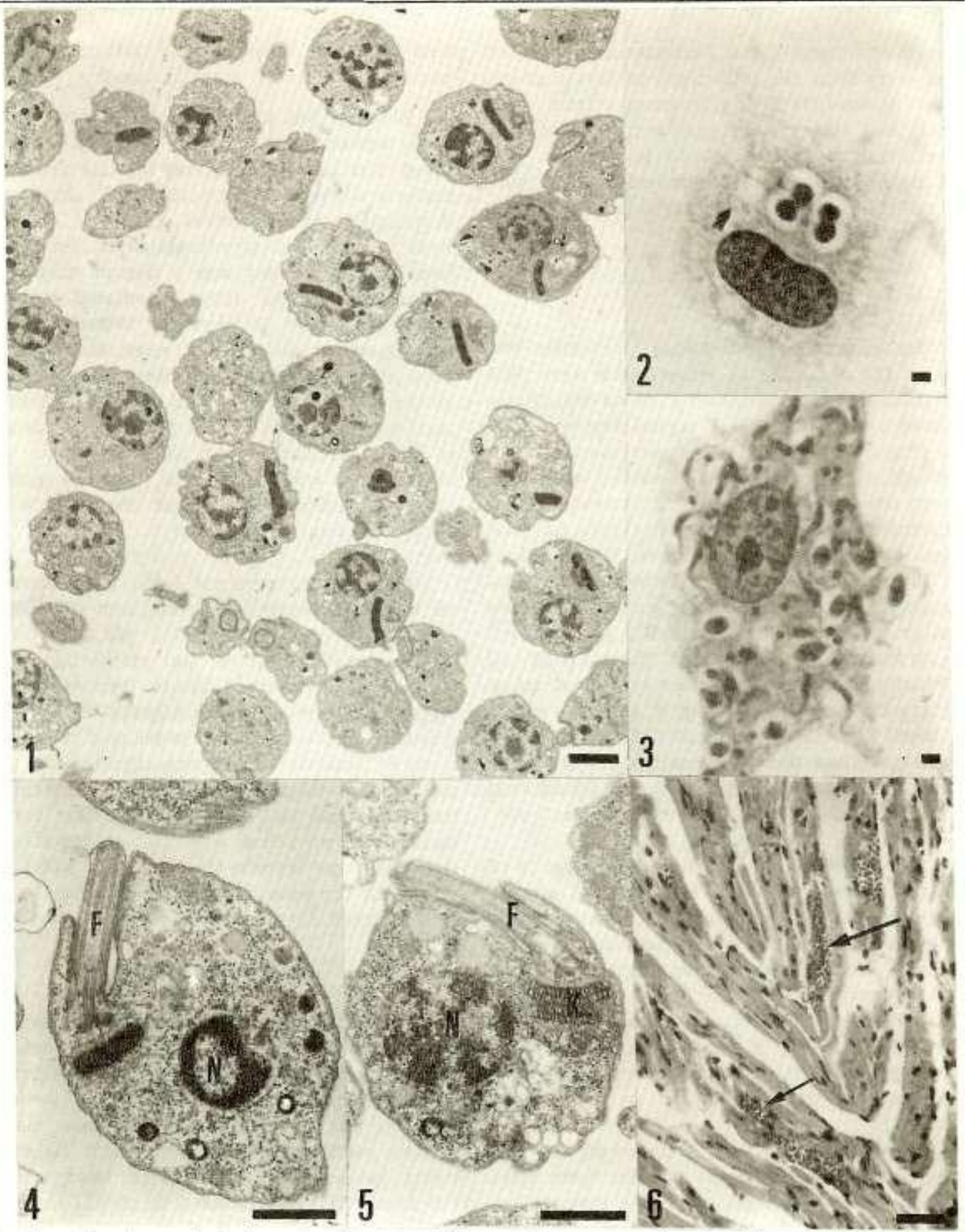

Fig. 1 - General aspect of the suspension of purified amastigotes as seen by transmislson electron mieroscopy X 7500. Bar $=1 \mu \mathrm{m}$

Fig. 2 - Photomicrograph of Giemsa-stained preparation showing dividing amastigotes after 24 h of T. cruxi-macrophage interaction. $\mathrm{X}$ soo. Bar $=10 \mu \mathrm{m}$.

Fig. 3 - Photomlerograph of Glemsa-stained preparation showing trypomastigotes, amastigotes and intermediate 1orms after 72 h of T. eruzi-macrophage interaction, $\mathrm{X} 300$. Bar $=10 \mu \mathrm{m}$.

Fig, 4:5 - Detail of two forms which are in process of transformation into trypomastigotes, as seen by transmission electron microscopy. They have a kinetoplast (K) laterally located in relation to the nucleus (N), and a short flagellum) (F). X 13.000. Bar $=1 \mu \mathrm{m}$

Fig. 6 - Histological section of the heart of a mouse sachificed 10 day after inoculation of amastigotes. Infected cells can be seen (arrows) $\mathrm{x} 150$. Bar $=50 \mathrm{\mu m}$ 
Carvalho, T. U. de \& SOUZA, W. de - Infectivity of amastigotes of Trypanosoma cruzj. Rev. Inst. Med. trop. São Paulo, 28:205.212, 1986.

T A B L E I

Ingestion of amastigote and opimastigote forms of Trypanosoma cruai by mouse peritoneal macrophages in vitro (1)

\begin{tabular}{lccc}
\hline $\begin{array}{c}\text { Developmental } \\
\text { form }\end{array}$ & $\begin{array}{c}\text { Time of } \\
\text { interaction (h) }\end{array}$ & Treatment & $\begin{array}{c}\text { Percentage of } \\
\text { infected } \\
\text { macrophages }\end{array}$ \\
\hline Amastigote & 2 & No & 2 \\
Amastigote & 6 & No & 2 \\
Amastigote & 24 & No & 8 \\
Amastigote & 2 & Trypsin & 1.5 \\
Amastigote & 3 & Trypsin & 1 \\
Epimastigote & 2 & No & 12.5 \\
\hline
\end{tabular}

(1) In all case the $\mathbf{T}$. cruzi-macrophage ratio was 10:1. Resuits from one representative experiment.

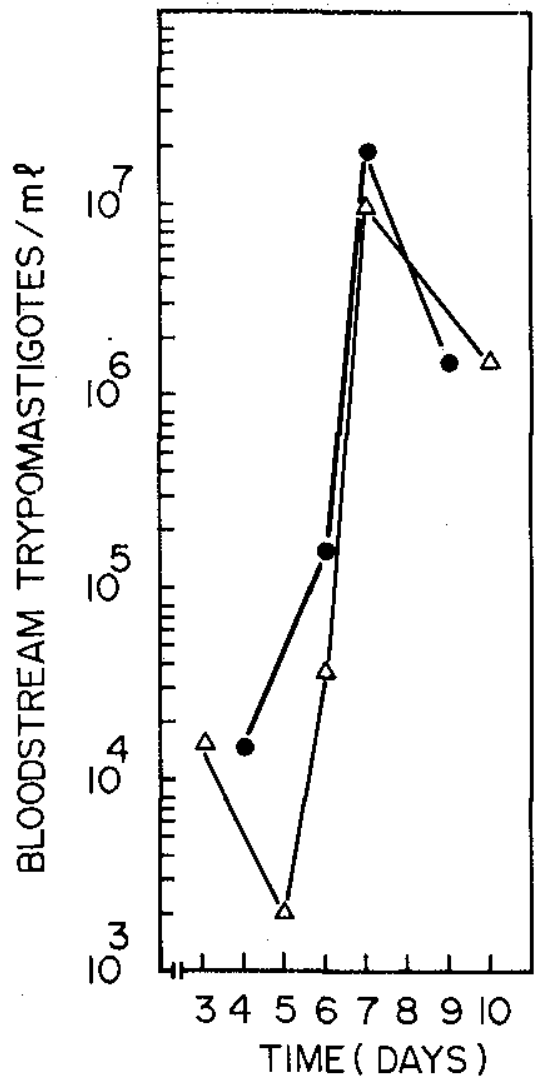

Fig. 7 - Parasitaemic curves in mice inoculated with $10^{\mathrm{s}}$ arnastigotes $(\Delta)$ or $10^{5}$ bloodstream trypomastigotes $(\bullet)$.

ritoneal macrophages in vivo (PAN ${ }^{23}$ ). When the Peru strain is cultivated in the presence of an estabilished cell line of Triatoma infestans embryo cells, rounded forms, which form clus. ters and which have been designated as "sta. phylomastigotes", appear. These forms divide outside the cells and are infective to mice, as seen by the appearance of bloodstream trypo.
T A B L E II

Susceptibility of T. cruzl to lysis by compiement $\left(^{*}\right)$

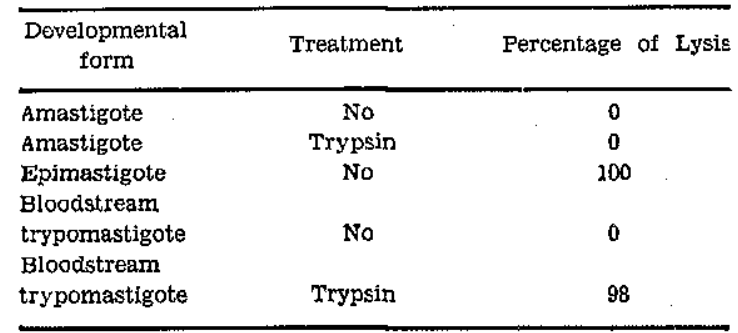

(*) Data are from one representative experiment

mastigotes in the inoculated animals (LANAR ${ }^{13}$ ). It has also been shown that rounded forms isolated by centrifugation of axenic cultures, are infective to mice (RIBEIRO et al. ${ }^{24}$; SEGURA et al. 25). Rounded forms found in clones of the CL strain were also infective (ANDRADE ${ }^{2)}$.

In relation to the possible infectivity of amastigotes obtained from vertebrate cells it was observed that some rounded forms released by macrophages in culture are ingested by normal macrophages and can reproduce the intracellular cycle of the parasite (BEHEBEHA$\mathrm{NI}{ }^{5)}$. When amastigotes are isolated from tis sues of animals infected with $\mathbf{T}$. cruzi, contra. ditory results have been reported. For instance, GUTTERIDGE et al. 10 showed that amasti. gotes, isolated from the muscle of heavly infected animals, are not infective for other animals. Others showed that amastigotes isolated from the spleen of mice were ingested by nor. mal mouse peritoneal macrophages where they were digested (CARVALFO et al. ${ }^{6}$ ). However, it was also shown that amastigotes isolated from the liver and the spleen of mice are infective to mice (ABRAHAMSON et al. ${ }^{1}$; McCABE et al. ${ }^{14)}$ and for macrophages in culture (McCABE et al. ${ }^{14}$; UMEZAWA et al, ${ }^{26}$ ).

Our observations show clearly that amas tigotes isolated from the supernatant of the ma crophage-like J774G8 cell line (CARVALHO \& SOUZA ${ }^{7)}$ and identified previously (CARVALHO et al.6) are infective to normal mouse macrophages in vitro as well as to mice. In the case of amastigotes it is interesting to point out that the percentages of macrophages which ingest amastigotes is much lower than that which is obtained when trypomastigote or epimastigote forms are used. This result is in contrast with previous observations (CAR. 
CARValHo, T. U. de \& SOUZA, W de - Infectivity of amastigotes of Trypanosoma cruzi. Rev; Inst. Med. trop. Säo Paulo, 28:205-212, 1986.

VALHO et al. ${ }^{6}$; UMEZAWA et al. ${ }^{26}$ ), which show that amastigotes isolated from the spleen of infected mice were readly ingested by macrophages. Treatment of the amasti. gotes with trypsin did not increase their ingestion by macrophages. It has been shown that trypsinization increases the uptake of bloodstream trypomastigotes by macrophages (ARAUJO JORGE \& SOUZA 4; KIPNIS et al. 12; NOGUEIRA et al. ${ }^{18}$ ). It is possible that the procedures used for the obtention of the amas. tigotes from the spleen interfered with the surface components of the parasites rendering them susceptible to ingestion by the macropha. ges. Careful examination of macrophage cultu. res fixed at various periods of interaction with T. cruzi showed that parasites proliferated within most cells which had ingested amastigo. tes.

It was reported recently that no amastigo. te-trypomastigote transformation occurred in macrophages infected with amastigotes of $\mathbf{T}$. cruzi (UMEZAWA et al, ${ }^{26)}$. In our macrophage cultures, however, the intracellular cycle was completed and trypomastigotes were found in the supernatant of cultures maintained in vi. tro for 72 hours.

Our results show that amastigotes are highly infective when inoculated into mice where a large number of trypomastigotes in the bloodstream, as well as in the peritoneal fluid of the animals, can be seen. It is interesting to note that the pattern of the parasitaemic curve of mice inoculated with amastigotes is similar to that observed with trypomastigotes, support. ing the view that this pattern is characteristic of the strain. The large number of cells containing parasites in the tissues of the mice infected with amastigotes is also an indication of the high infectivity of these forms. It was shown recently that amastigotes obtained from the fibrosarcoma line $\mathrm{M}_{4}$ are infective for mice, producing low-grade infections in normal mice and acute fatal infection in mice previously ir. radiated (HUDSON et aI, 1 ).

It is well known that while trypomastigo. tes are resistant, epimastigotes are highly susceptible to complement-mediated lysis (MUNIZ \& BORRIELO 16; NOGUEIRA et al. ${ }^{17}$ ). In the case of trypomastigotes it was shown that also this form became susceptible to the comple. ment mediated lysis when the parasites were treated with trypsin (KIPNIS et al. 12). Our data confirm all these observations and extend them to the amastigotes, showing, however, that this form is highly resistant to complementmediated lysis even after trypsin treament. This observation is in close agreement with previous results showing that rounded forms, obtained by incubation of trypomastigote or epimastigote forms of $\mathbf{T}$. cruzi in axenic medium (ENGEL et al. ${ }^{9}$ ), are resistant to complement-mediated lysis.

All these data suggest that amastigotes are resistant to complement-mediated lysis and are able to infect vertebrate cells. It is possible that infection of vertebrate cells in vivo by amastigotes occurs mainly in the acute phase of Chagas' disease. Ultrastructural observations of heart tissue of mice heavily infected shows. occasionaly, the presence of amastigotes in the intercellular space (DE SOUZA, unpublished observations). Similar observations have been reported previously (BEHEBEHANI ${ }^{5}$ ). Studies carried out in vitro have shown that at the end of an intracellular cycle the amastigote-trypomastigote transformation is not synchronous so that when the cell has ruptured there is release of trypomastigotes, intermediate forms and also some amastigotes. Therefore it is possible that also these amastigotes may contribute to the spreading of the infection in the vertebrate host.

\section{RESUMO}

\section{Infecciosidade da forma amastigota do Trypanosoma cruzi}

A infecciosidade da forma amastigota do Trypanosoma cruzi, isolada do sobrenadante de culturas da linhagem tumoral de macrófago J774G8 previamente infectada com formas tri. pomastigotas, para macrófagos normais manti dos in vitro, foi analisada. Apenas $2 \%$ dos ma. crófagos ingeriram amastigotas quando o pe ríodo de interação parasito-cèlula era de 1 hora enquanto que para este mesmo período $12 \%$ dos macrófagos ingeriram formas epimastigotas. Tratamento prévio do amastigotas com tripsina não interferiu na sua ingestão por macrófagos. Uma vez no interior dos macrófa. gos os amastigotas se dividiam e posteriormen. te transformavam-se em tripomastigotas. A for. ma amastigota mostrou-se altamente infectiva 
CARVALHO, T. U. de \& SOUZA, W. de - Infectivity of amastigotes of Trypanosoma cruzi. Rev. Inst. Med. trop. São

Paulo, 28:205.212, 1986.

quando inoculada na cavidade peritoneal de camundongos, induzindo altos níveis parasitêmicos e parasitismo tecidual. Os amastigotas, nāo são lisados quando incubados na presença de soro fresco de cobaio à semelhança do que tem sido descrito para tripomastigotas. No entanto, ao contrário do que ocorre com tripomastigotas, os amastigotas não são lisados mesmo após prévia tripsinização.

\section{ACKNOWLEDGEMENTS}

This work has been supported by UNDP/ World Bank/WHO Special Programme for Re. search and Training in Tropical Diseases, Con. selho Nacional de Desenvolvimento Científico e Tecnologico ( $\mathrm{CNPq}$ ), Financiadora de Estudos e Projetos (FINEP) and Conselho de Ensino para Graduados da UFRJ.

\section{REFERENCES}

1. ABRAHAMSON, I. A.; KATZIN, A. M. \& MXXDER, R. V. - A method for isolating Trypanosoma cruzi amas. tigotes from spleen and liver using two-step discon. tinuous gradient centrifugation. J. Parasit., 69: 437. $439,1983$.

2. ANDRADE, P. P. de - Clonagem de tripanosomatideos em meio nutriente sólido. Rio de Janeiro, 1983. ( $\mathrm{PhD}$. Thesis - Instituto de Biofisica da Universidade Federal do Rio de Janeiro).

3. ARAUJO, F. G.; HANDMAN, E. \& REMINGTON, J. S. - Binding of lectins to the cell surface of Trypanosoma cruzi. J. Protozool., 27: 397-400, 1980.

4. ARAÛJO-JORGE, T. C. \& SOUZA, W. de - Effect of carbohydrates, periodate and enzymes in the process of endocytosis of Trypanosoma crozi by macrophages. Acta trop. (Basel), 41: 17-28, 1984.

5. BEHEBEHANI, K. - Developmental cycles of Try. panosoma (Schizotrypanum) cruzl (Chagas, 1909) in mouse peritoneal macrophages in vitro. Parasitology. 66: $343-353,1973$.

6. CARVALHO, R. M. G.; MEIRELLES, M. N. L.; SOUZA, W. do \& LEON, $W$. - Isolation of the intracellular stage of Trypanosoma cruzi and its interaction with mouse macrophages in vitro. Infeet. Immun., 33: 546-554, 1981 .

7. CARVALHO, T. U. de \& SOUZA, W. de - Separation of amastigotes and trypomastigotes of Trypanosoma cruzi from cultured cell. $\mathbf{Z}$. Parasitenk., 69: 571-575, 1983.

8. CARVALHO, T. U. de; SOUTO-PADRON, T. \& SOUZA, W. de - Trypanosoma cruzi: surface charge and freezefracture of amastigotes. Exp. Parasit., 59: 12-23, 1985.
9. ENGEL, J. C.; DVORAK, J. A. \& SEGURA, E. L. Simpie cell-free culture protocol allows production and characterization of Trypanosoma cruzi amastigotes. Molec. Biochem. Parasit., (suppl.): 589, 1982. (Abstract).

10. GUTTERIDGE, W. E.; COVER, B. \& GABORAK, M. - Isolation of blood and intracellular forms of Trypanosoma cruzi from rats and other rodents and preIiminary studies of their metabolism, Parasitology, 76: $159 \cdot 176,1978$.

11. HUDSON, L.; SNARY, D. \& MORGAN, S. J. - Try. panosoma cruzi: continuous cultivation with murine cell lines. Parasitology, 88; 283.294, 1984.

12. KIPNIS, T. L.; DAVID, J. R.; ALPER, C. A.; SHER, A. \& DIAS DA SILVA, W. - Enzymatic treatment transforms trypomastigotes of Trypanosoma cruzi into activators of alternative complement pathway and potentiates their uptaise by macrophages. Proc. nat. Acad. Sci. (Wash.), 78: 602-605, 1981.

13. LANAR, D. E. - Growth and differentiation of Trypanosoma cruzi cultivated with a Triatoma infectans embryo cell line. J. Protozool., 26: 437-462, 1979.

14. MCCABE, R. E.; REMINGTON, J. S. \& ARAƯJO, F. G. - Mechanisms of invasion and replication of the intracellular stage in Trypanosoma cruzj. Infect Im. mun., 46: 372-376, 1984.

15. MARIA, T. A. - Estudo comparativo da ultra-estrutura de amastigotas do Trypanosoma cruzi obtidas do vertebrado e em meio líquido. Belo Horizonte, 1975. (MSc Thesis - Universidade Federal de Minas Gerais).

16. MUNIZ, J. \& BORRIELO, A. - Estudo sobre a ação litica de diferentes soros sobre as formas de cultura $\Theta$ sanguícolas do Schizotrypanum cruzi. Rev. bras. Biol., 5: 563-576, 1945.

17. NOGUEIRA, N.; BIANCO, C. \& COHN, Z. - studies on the selective lysis and purification of Trypa. nosoma cruzi. J. exp. Med., 142; 224-229, 1975.

18. NOGUEIRA, N.; CHAPLAN, S. \& COHN, Z. - Try. panosoma cruzi: factors modifying ingestion and fate of blood form trypomastigotes. J. exp. Med., 152: $447.451,1980$

19. NOGUEIRA, N. \& COHN, Z, - Trypanosoma cruzl: mechanism of entry and intracellular fate in mam. malian cells. J. exp. Med., 143: 224.229, 1976.

20. PAN, C. T. - Cultivation of the leishmaniform stage of Trypanosama cruzi in cell-free media at different. temperatures. Amer. J. trop. Med. Hyg., 17: 823.832, 1968.

21. PAN, C. T. - Cultivation and morphogenesis of Trypanosona cruzi in improved liquid media. J. Protozool., 18: 556-560, 1971.

22. PAN, C. T. - Trypanosoma cruzi: intracellular stages grown in a cell-free medium at $37^{\circ} \mathrm{C}$. Exp. Parasit. 45: 215-224, 1978a. 
CARVALKO, T. U. de \& SOUZA, W. de - Infectivity of amastigotes of Trypanosoma cruzi. Rev. Inst. Med. trop. São Paulo, 28:205-212, 1986 .

23. PAN, S, C. - Trypanosoma cruzi: in vitro interactions between cultured amastigotes and human skin-muscle cells. Exp. Parasit., 45: 274-286, 1978b.

24. RIBEIRO, R. D.; BELDA NETO, F. M. \& FERRIOLI FILHO, F. - Sub-amostras do T, cruzi obtidas por centrifugaçāo diferencial de formas de cultura em meio liquido. I. Amostra Bolivia - Comportamento no hospedeiro vertebrado. In: CONGRESSO INTERNACIONAL SOBRE DOENÇA DE CHAGAS, Rio de Janeiro, 1979. Anals. p. 31 .

25. SEGURA, E. L.; SUBIAS, E.; ESTEVA, M.; MECKERT, P. C.; BRONZINA, A. \& JAGUENS, R. P. - Characteristicas de ínfectividad de tres poblaciones de cultivo de Trypanosoma cruzl. Medicina (B. Aires), 40: 97. 102, 1980.
26. UMEZAWA, E. S.; MILDER, R. V. \& ABRAHAMSON, I. A. - Trypanosoma cruzi amastigotes; development in vitro and infectivity in vivo of the forms isolated from spleen and liver. Acta trop. (Basel), 42: 25-32, 1985.

27. VILLALTA, F. \& KIERSZENBAUM, F. - Growth of isolated amastigotes of Trypanosoma cruzl in cell free medium. J. Protozool., 29: 570-576, 1982.

28. WARREN, L. - Metabolism of Schlzotrypanum cruzi, Chagas. Effect of culture age and substrate concen. tration on respiratory rate, J. Parasit., 46: 529-539, 1960

Recebiđo para publicação em 22/7/1985. 